\title{
Digital Literacy and Identity Formation in 21st Century Classrooms: Implications for Second Language Development
}

\author{
Lavern Byfield (Corresponding author) \\ Department of Curriculum and Instruction, Southern Illinois University Carbondale \\ 625 Wham Drive MC 4610, Carbondale, IL, U.S.A. \\ E-mail: byfield2@siu.edu \\ Crystal Shelby-Caffey \\ Department of Curriculum and Instruction, Southern Illinois University Carbondale \\ 625 Wham Drive MC 4610, Carbondale, IL, U.S.A. \\ E-mail: ccaffey@siu.edu \\ Heidi Bacon \\ Department of Curriculum and Instruction, Southern Illinois University Carbondale \\ 625 Wham Drive MC 4610, Carbondale, IL, U.S.A. \\ E-mail: hrbacon@siu.edu \\ Xiang Shen \\ Department of Curriculum and Instruction, Southern Illinois University Carbondale \\ 625 Wham Drive MC 4610, Carbondale, IL, U.S.A.
}

Received: 06-05-2015

Published: 01-01-2016
Accepted: 20-08-2015

doi:10.7575/aiac.ijalel.v.5n.1p.39
Advance Access Published: October 2015

URL: http://dx.doi.org/10.7575/aiac.ijalel.v.5n.1p.39

\begin{abstract}
As technology is increasingly adapted for educational purposes, previous research has confirmed the impact of technology on English learners' (ELs') literacy development. Given the increased attention to self-based studies in second language acquisition, this paper explores how ELs are motivated to learn a second language by pursuing the imagined selves, investing in the target culture, and negotiating identities in digitally mediated contexts. The motivational capacity of identity is discussed from cognitive/psychological, social/psychological, and sociocultural perspectives. Pedagogical implications about the use of technology to facilitate L2 literacy development are discussed.
\end{abstract}

Keywords: L2 motivational self systems, cultural investment, L2 socialization, digital literacy

\section{Introduction}

As English is developing as the lingua franca, there is a simultaneous proliferation in new information and communication technologies (ICTs). English as lingua franca refers to communications in English by speakers whose native language is other than English (Seidlhofer, 2005). English is no longer learned as a content subject only for passing high-stakes examinations and, the reach of ICTs extends far beyond the classroom and impacts every facet of life. The ability to communicate in English has been viewed as central to helping English learners (ELs) achieve greater success in their future professional development. Likewise, one's development of the requisite skills for navigating digital terrains is fundamental to successful participation in the global conversations of the 21 st century.

Similar to other categorizations such as race, ethnicity, gender or class, speaking English as a second or other language is another way of classifying differences that impact people's linguistic identities and future trajectories (Duff, 2012). The New London Group (1996) explains that when we look to create learning conditions for "full social participation, the issue of differences becomes critically important" (p. 60). These differences "allow people to be caught or acquired by a collective representation enforced by convention and conversation" (McDermott, Raley, \& Seyer-Ochi, 2009, p. 102). As such, categorizations are more about group rather than individual differences, and they often serve as gatekeepers that limit and constrain individuals' imagined futures (Kanno \& Norton, 2003; Moje \& Luke, 2009; Norton \& Pavlenko, 2004; Norton \& Toohey, 2011). With the rapid increase of ELs in U. S. classrooms and limited access to resources (for many students), we discuss the impact ICTs may have on ELs' identity formation and motivation to learn a second language.

This article examines the intersection of identity formation, motivation to learn a second language, and digital literacy in 21 st century classrooms: Identity theory is used to discuss second language learning. Given the current demographic trend in U. S. schools and the growing number of students who are speakers of languages other than English, meeting the diverse needs of students is at the forefront of discussions regarding improving academic achievement for all 
students (Commins \& Miramontes, 2005; Lessow-Hurley, 2013). Furthermore, given the changing definition of what it means to be literate in the 21 st century, we use identity theory to discuss how ELs negotiate their identities within and across multiple spaces.

\section{Literature Review and Theoretical Framework 2.1 Why Is Identity Considered in SLA?}

Duff (2012) makes clear that in the field of second language acquisition (SLA), descriptors and labels of difference have "foregrounded" certain aspects of ELs' lives, abilities, and identities (p. 410). These descriptors further reflect theoretical framing in SLA that ascribes various identities to ELs such as interlanguage speakers, immigrants, limited proficient speakers, advanced second language (L2) speakers, etc. Being ascribed to an identity significantly impacts ELs' motivation and investment to learn a second language; it further impacts the ways in which they position themselves and are positioned by others (Duff, 2012; Norton, 2000).

Defining identity can be confusing (Esteban-Guitart \& Moll, 2014; Holland \& Lachicotte, 2007). To operationalize this abstract concept, Norton (2000) employs Weedon's (1987) concept of subjectivity to describe identity as an individual's perception of his or her relationship to the environment and this relationship is constructed. Holland and Lachicotte further expand on identity to include how one's sense of self is formed in relation to the "inhabiting roles, positions, and imaginaries that matter to them" (p. 103). Subsequently, static and deterministic biological and social aspects of identity have given way to identities that are "negotiated," socially constructed, and dynamic (Norton, p. 125).

According to Norton (1995), the field of SLA has not adequately addressed the ways in which relations of power inform social interactions between ELs and native speakers, and these interactions and subjectivities are always imbued in relations of power. Economic literacy capital, e.g., Internet access, technology resources, private tutoring, and other resources are often allocated and distributed based on social class and power (Compton Lilly 2007; Luke 2004; Warschauer, 2010). Therefore, Luke challenges us to question the "material consequences" of languages and literacies that are highly privileged and sanctioned by the state and other globalized educational systems (p. 334). Previous studies on ELs' identities are committed to understanding how the changes of learners' identities, for different purposes and in various contexts, affect their second language learning (Norton, 2000, 2012; Duff, 2002). However, there is a need for empirical research that examines identity formation, motivation to learn a second language, and digital literacy in 21 st century classrooms.

Identity and agency are key concepts in SLA (Duff, 2012). Duff defines agency “ as "people's ability to make choices, take control, self-regulate, and thereby pursue their goals as individuals, leading, potentially, to personal or social transformation" (p. 417). ELs are not complicit or passive language learners; they make informed decisions, exert influence, engage in acts of resistance, or choose to comply (Duff). Where silence is frequently seen as an act of resistance, according to Duff, ELs often use silence to protect themselves from humiliation. Tabouret-Keller (1985, as cited in Pavlenko, 2001) makes the point that each act of speaking or silence is an act of identity for lingua franca speakers, and such acts are agentive in nature.

ELs negotiate their identities and reposition themselves in learning communities in order to gain access to capital and other resources. Duff (2012) maintains that "those who typically feel the most control over their lives, choices, and circumstances also have the power - the human, social, or cultural capital and ability — they need to succeed" (p. 417).

\subsection{How is Identity Related to SLA?}

Identity emerged as a term in sociology and was introduced into the area of SLA in the latter part of the 20th century (Norton Pierce, 1995; Norton, 2000; Norton \& Toohey, 2012). Various constructs have been developed and aimed at explaining second language learning from cognitive/psychological, social/psychological, and sociocultural perspectives (Dörnyei, 2005; Duff, 2002; Norton, 2000). As English is now considered a lingua franca, speaking English is often aligned with the identity of ELs and the view of "self." As discussed, the cognitive/psychological perspective has shifted to "doing self" rather than the traditional personality-based "being self" (Dörnyei, 2005). In response, Dörnyei $(2005,2009)$ advanced an "L2 [second language] motivational self-system" to paradigmatically reframe L2 motivation theories from static and context-dependence to dynamic and self-oriented. Driven by the disconnection between selfimagined selves and here-and-now selves, ELs are motivated to learn their L2 in order to bridge this disconnect (Dörnyei, 2009).

SLA research in an attempt to view motivation in more socially situated and dynamic ways has taken up Norton's notion of investment (Duff, 2012). Norton (1995; 2000) employs the economic metaphor of investment to "make meaningful connections between a learner's desire and commitment to learn a language and their changing identities" (Norton \& Toohey, 2011, p. 415). Norton (1995; cf. Norton and Toohey) takes the position that if learners invest in the target language, they will receive a capital return on the value of their investment in the form of resources that would have otherwise been unattainable. "This return on investment must be seen as commensurate with the effort expended on learning the second language" (Norton, 1995, p. 17). As identities are multilayered and ever-changing, they must be understood within this landscape (Norton, 1997, 2000, 2001).

Within this landscape of shifting identities, ELs are often positioned based on how their identities are perceived by others (Duff, 2012). Wortham (2004) defines positioning as "an event of identification, in which a recognizable category of identity gets explicitly or implicitly applied to an individual in an event that takes place across seconds, minutes, or hours" (p. 166). Acts of positioning call individuals into an identity, and so, by virtue of either accepting or resisting such positioning, individuals are self-authoring (Holland \& Leander, 2004). 
Using social practice theory and communities of practice, Duff (2012) describes how ELs are often viewed subjectively as legitimate or illegitimate participants by others (Lave \& Wenger, 1991). Concomitantly, a community of practice relationally links both membership and practice (Garrett \& Baquedano-Lopez, 2002) where all participants regardless of their level of participation are considered full, legitimate participants (Lave \& Wenger, 1991). Adopting this stance, Duff (2012) argues that ELs can take agentive action and re-frame their identities, potentially from illegitimate to legitimate or incapable to capable, etc, through interactions with more experienced others through mutual engagement, joint enterprise, and a shared repertoire (Lave \& Wenger; Wenger, 1998). In a community of practice, participants work towards mutual goals and come to see themselves in the other (Wenger). They have the potential to re-imagine their identities and their imagined futures.

\subsection{What does it mean to be literate in the 21 st century?}

Several scholars discuss the impact of new technologies on contemporary definitions of literacy and the implications for classroom instruction (Dobson \& Willinsky, 2009; Lankshear \& Knobel, 2011; Leu, Kinzer, Coiro, \& Cammack, 2004; Leu, Mallette, Karchmer, \& Kara-Soteriou, 2005; Taffe \& Bauer, 2013; Tysseling, 2015). Lankshear \& Knobel (2011) contend that new literacies materialize as social practices evolve through multiple modalities that are technologically mediated. Language use has been redefined with $21^{\text {st }}$ century literacy practices and therefore, we recognize that involvement with new literacies demands that we have literacy skills specific to a certain technology. Essentially, while the literacy requirements for creating a digital story are similar to those needed for participation on Facebook or Twitter, there are very distinct differences and a person must be competent in both the similarities and differences to be considered literate within these environs. Given the changing definition of what it means to be literate, educators and students are creating new social paradigms that expand the confines of language and literacy. This necessitates an examination of the multiple uses of technology and new media in classrooms at various levels. In essence, we take into consideration the implications of technology usage in educational spaces and its evolution and the impact on the teaching/learning process.

With the prevalence of digital technologies, many scholars discuss the ramifications on literacy instruction (Coiro, Knobel, Lanskhear, \& Leu, 2008a; Lankshear \& Knobel, 2011; Shelby-Caffey, Caffey, Caffey, \& Caffey, 2014). These authors argue that with the advent of the Internet there has been a shift in both the "speed and the scale of change in the technologies for literacy, forcing us to directly confront the issue of new literacies" (Coiro, Knobel, Lanskhear, \& Leu, 2008a, p. 3). The introduction of Web 2.0 and related digital technologies provides incomparable prospects to associate with and acquire knowledge globally. According to Crane (2009) $21^{\text {st }}$ century learning experiences are more handson/experiential than previous decades as students explore digital media. Crane argues that social learning and networking in addition to consumers' production, contribution, consumption, and acquisition of knowledge are hallmarks of contemporary society.

\subsection{How is SLA mediated as ELs negotiate participation in digital spaces?}

The communities of practice in which ELs and native speakers alike engage, place increasing demands on participants to be literate in digital spaces. There are "demands that a literate person possess a wide range of abilities and competencies, many literacies. These literacies, from reading online newspapers to participating in virtual classrooms, are multiple, dynamic, and malleable" (National Council of Teachers of English, 2008). Likewise, Ohler (2009) discussed the need for individuals to be familiar with varied forms of new media as well as how to "integrate these new media forms into a single narrative, or "media collage," such as a webpage, blog, or digital story". Each of these technologies imposes a particular social construction of what it means to be literate within a given environment or using a given technology.

Digital literacy, as a new form of literacy in the 21st century, has been brought into the classroom for both native language (L1) and L2 literacy development. According to Martin (2006), digital literacy:

is the awareness, attitude and ability of individuals to appropriately use digital tools and facilities to identify, access, manage, integrate, evaluate, analyze and synthesize digital resources, construct new knowledge, create media expressions, and communicate with others, in the context of specific life situations, in order to enable constructive social action; and to reflect upon this process. (p. 19)

Within the context of virtual spaces, there are possibilities for ELs to assert agency as they negotiate an identity. Lam's (2009) study documented how an immigrant girl from China used instant messaging to maintain local, translocal, and transnational linguistic identities and mobilize resources within multiple linguistic communities. Evidence of selfauthoring (Holland \& Leander, 2004) is revealed during closer examination of ELs interactions in digital spaces. Black (2009) found, in her study on young learners' role play writing in online fan fiction, that, by interacting with diverse readers via the Internet, young learners are able to create their imagined selves---living in their self-created worlds. In effect, ELs display agency as they negotiate identities in virtual spaces; Identities that are multilayered, dynamic, and ever-changing. In line with Ivanič's (1998) contention, the ELs in both Lam's (2009) and Black's (2009) studies exhibit the ability to fluidly reconstruct identities as needed to navigate digital spaces. The ELs' reconceptualization of identity is self-authored and works to position them within a given community.

While the identities within digital spaces are self-authored, "we should recognize that in order to develop literacy or to successfully participate in a given Social Networking Site (SNS), one must recognize and act in accordance with certain norms of behavior that the site recognizes as valuable and be cognizant of how others might interpret behaviors" 
(Kimmons, 2014, p. 96). The desire to learn the appropriate means for communicating within these digital spaces serves as both a motivating factor for ELs and reinforcement of a sense of self and cultural capital.

Norton and Williams (2012) found that as students are more invested in the eGranary, an electronic device functioning as "a library in the box", the range of identities they could imagine in the present and future were greatly expanded. Similarly, Curwood, Magnifico, and Lammers (2013) discovered that learners' motivation in writing can be greatly enhanced through sharing their creative works with authentic audience in online spaces. This work seems to highlight how ELs' desire/motivation to operate within digital spaces allows opportunities for self-expression, while concomitantly shaping the forms of expression, and thus ELs' identity. In this regard, second language acquisition may be mediated as ELs negotiate participation in digital spaces.

The potential to reframe identities and reimagine lives and communities is powerful. Still Lewis, Enciso, and Moje (2007) assert that "the individual and community are both under theorized in sociocultural theory" (p. 5). They call on researchers to "focus on how identities are shaped by the shaping of social and cultural contexts...one that looks carefully at the macro as it shapes the micro" (p. 5). We take up Lewis et al.'s call to look more closely at the social and cultural contexts of identity formation in English as a Foreign Language (EFL) and English as a Second Language (ESL) as we examine the intersection of motivation, investment, and desire in a global community that shapes local classrooms.

Hall, Jury, and Sachar (2007), drawing on Bruner (1994), introduce the notion of turning points---moments of selfrealization and actualization that are deeply agentive and shape our constructions of self. This notion of turning points can be juxtaposed with Motha and Lin's (2014) conception of desire. Motha and Lin contend that desire is at the core of learning English as a Foreign Language (EFL) and ESL. In this way, motivation to learn, investment, and desire are interconnected (Motha \& Lin); desire undergirds ELs' motivation to learn and invest in the target language.

Desire is, therefore, an intrinsic part of one's identity and imagined self and community (Kanno \& Norton, 2003). It is imbued with a sense of hope that affirms. Kanno and Norton, maintain that "Hope is constituted in the need to imagine an alternate human world and to imagine it in a way that enables one to act in the present as if this alternative had already begun to emerge" (p. 244). The idea of imagining an alternative world to act in the present is indicative of acting in a particular way as to bring about a desired outcome. In this case, it epitomizes desire, a realm of possibility that leads one to act. This action is attributed internally (Bruner, 1994) and connected to happenings outside the self. In other words, desire underlies the action that is "believed to lie behind the doors that English unlocks" (Motha \& Lin, 2014, p. 332). This then begs the question raised by Motha and Lin as to what makes learning English, whether EFL or ESL, such a desirable pursuit? And how are agency and control over one's language learning supported by digital literacies across cultural and linguistic borders (Benson, 2013)?

To answer these questions, we look to social inclusion in its broadest sense, as proposed by Kubota (2011), which speaks to aspirations or hopes and desires to be included in both global and local imagined communities. According to Kubota, the desire and prestige of English as Lingua Franca connects people in a global community, even though a majority of the world is non-English speakers. For EFL students in schools and universities, English competency can lead to increased earning potential and higher socio-economic status (Kubota), providing entrée into the global Englishspeaking community. This inclusion or connectedness fulfills one's need to affiliate, to belong to something larger than oneself.

Benson's (2013) definition of autonomous learning informs our understanding of how digital literacies attends to the macro by shaping the micro. According to Benson, autonomous learning refers to learners having control over their own learning. Invoking a socio-cultural framing, we can think of autonomy as a form of agency where learners not only control their means of access, they have control over processes and content. Benson points out that in years past, a lack of English language resources constrained learning in EFL classrooms; today, however, the Internet provides a multitude of resources, and ELs are bypassing the constraints of limited classrooms by going on-line. In the past, programs were designed to train learners to be self-directed, an institutionalized form of control; however, in today's knowledge economy digital literacies afford ELs the freedom to create socially constructed spaces for creative inquiry.

\section{Implications/Conclusions}

The use of technology is a contemporary issue in mainstream classrooms which is attracting growing attention in the field. We broach this subject centered on how second language learning is mediated by ELs' negotiations of various identities through digital literacy. By exploring the intersection of identity formation, digital literacy, and second language development, we argue that ELs' identities are inextricably connected with technology. Given the changing demographic and technological landscape of 21 st century classrooms, the onus is on educators to create learning environments that will promote language development and prepare students to navigate technologically diverse learning spaces.

Globalization has moved English, as lingua franca, beyond learning English as a content subject. No longer is it viewed with the unitary goal of passing a high-stakes test or entrance examination. Instead, the ability to communicate in English has been viewed as central to helping ELs and native speakers alike participate in global conversations mediated within digital spaces. It is further interesting to note that a majority of conversations in English are conducted by non-native speakers, and yet, native speakers continue to hold sway over what is perceived to be correct and proper usage (Seidlhofer, 2005). 
Through the use of identity theory (Duff, 2012), we argue that there are several variables that interplay in learning a second language in contemporary classrooms. We argue that second language learning is mediated by ELs' negotiations of various identities as they navigate digital spaces. By exploring the intersection of identity formation, digital literacy, and second language development, there are several implications for English as a Second Language (ESL) and contentarea instruction. ELs negotiate their identities and reposition themselves in learning communities in order to gain access to capital and other resources.

Educators must develop awareness of ELs' ability to adopt identities that serve them well in various environments. In addition, there exists an opportunity for educators to capitalize on ELs' motivation to interact within digital spaces and assist them in establishing and negotiating their identities in digitally mediated contexts.

Defining identity is muddled and mystifying (Esteban-Guitart \& Moll, 2014; Holland \& Lachicotte, 2007) due to several factors including, how individuals situate themselves in relation to the world. Hence, Norton argues that identities are "negotiated," (emphasis our own) socially constructed, and dynamic (Norton, p. 125). As ELs negotiate their identities and reposition themselves in learning communities, they gain access to capital and other resources. Duff (2012) posits that "those who typically feel the most control over their lives, choices, and circumstances also have the power----the human, social, or cultural capital and ability----they need to succeed" (p. 417). As discussed above, previous studies on ELs' identities take into account how changes in learners' identities, for different purposes and in various contexts, affect their second language learning (Duff, 2002; Norton, 2000, 2012. Therefore, various theories aim at extrapolating second language second language learning from cognitive/psychological, social/psychological, and sociocultural perspectives (Dörnyei, 2005; Duff, 2002; Norton, 2000). Educators would do well to create opportunities in which ELs can access digital literacies and position themselves as contributors in local and global connected learning communities.

\section{References}

Benson, P. (2013). Learner autonomy. TESOL Quarterly, 47(4), 839-843.

Black, R. W. (2009). Online fan fiction, global identities, and imagination. Educational Leaderships, 43(4), $397-425$.

Bruner, J. (1994). The "remembered" self. In U. Neisser \& R. Fivush (Eds.), The remembering self: Construction and accuracy in the self-narrative (pp. 41-54).Cambridge, UK: Cambridge University Press.

Coiro, J., Knobel, M., Lankshear, C., \& Leu, D. J. (2008a). Central issues in new literacies and new literacies research. In J. Coiro, M. Knobel, C. Lankshear, \& D. J. Leu (Eds.), Handbook of research on new literacies (pp.1-21). New York: Erlbaum.

Commins, N. L., \& Miramontes, O. B. (2005). Linguistic diversity and teaching. Mahwah, NJ: Lawrence Erlbaum Associates.

Compton Lilly, C. (2007). The complexities of reading capital in two Puerto Rican families. Reading Research Quarterly, 42(1), 72-98.

Crane, B. E. (2009). Using WEB 2.0 tools in the K-12 classroom New York: Neal-Schuman.

Curwood, J. S., Magnifico, A. M., \& Lammers, J. C. (2013). Writing in the Wild Writers' Motivation in Fan-Based Affinity Spaces. Journal of Adolescent \& Adult Literacy, 56(8), 677-685. doi: 10.1002/JAAL.192

Dobson, T., \& Willinsky, J. (2009). Digital literacy. In D. R. Olson \& N. Torrance (Eds.), The Cambridge handbook of literacy (pp. 286-312). Cambridge: Cambridge University Press.

Dörnyei, Z. (2005). The psychology of the language learner: Individual differences in second language acquisition. Mahwah, NJ: Erlbaum.

Dörnyei, Z. (2009). The L2 Motivational Self System. In Z. Dörnyei \& E. Ushioda (Eds.), Motivation, language identity and the L2 self (pp. 9-42). Tonawanda, US: Multilingual Matters.

Duff, P. (2002). The discursive co-construction of knowledge, identity, and difference: An ethnography of communication in the high school mainstream. Applied Linguistics, 23, 289-322.

Duff, P. (2012). Identity, agency, and second language acquisition. In S. M. Gass \& A. Mackey (Eds.), The Routledge handbook of second language acquisition (Vol. 14, pp. 410-441). New York, NY: Routledge.

Esteban-Guitart, M. \& Moll, L. (2013). Funds of identity: A new concept based on the funds of knowledge approach. Culture \& Psychology, 20(1), 31-48.

Garret, P.B. \& Banquedano-Lopez, P. (2002). Language socialization: Reproduction and continuity, transformation and change. Annual Review of Anthropology. (31), 339-361.

Gee, J.P. (2008). Social linguistics and literacies: Ideologies in discourses (3 ${ }^{\text {rd }}$ ed.). New York, NY: Routledge.

Holland, D., \& Leander, K. (2004). Ethnographic studies of positioning and subjectivity: An introduction. Ethos, 32(2), 127-129.

Holland, D. \& Lachicotte, W. Jr. (2007). Vygotsky, Mead, and the new sociocultural studies of identity. In H. Daniels, M. Cole, \& J Wertsch (Eds.), The Cambridge companion to Vygotsky (pp. 101-135). New York, NY: Cambridge University Press. 
Hull, G., Jury, M. \& Zacher, J. (2007). Possible selves: Literacy, identity, and development in work, school, and community. In A. Belzer, Toward defining and improving quality in $\quad$ adult based education (pp. 299-318). New York, NY: Routledge.

Ivanič, R. (1998). Writing and identity: The discoursal construction of identity in academic writing Philadelphia, PA: John Benjamins.

Kanno Y., \& Norton, B. (2003). Imagined communities and educational possibilities. Journal of Language, Identity, and Education, 2(4), 241-249.

Kimmons, R. (2014). Social networking sites, literacy, and the authentic identity problem. TechTrends:Linking Research \& Practice to Improve Learning, 58(2), 93-98.

Kubota, R. (2011). Learning a foreign language as leisure and consumption: Enjoyment, desire, and the business of learning eikaiwa, International Journal of Bilingual Education and Bilingualism, 41(4), 473-488.

Lam, W. S. E. (2009). Multiliteracies on Instant Messaging in Negotiating Local, Translocal, and Transnational Affiliations: A Case of an Adolescent Immigrant. Reading Research Quarterly, 377-397.

Lankshear, C., \& Knobel, M. (2011). New literacies: Everyday practices and social learning (3 ${ }^{\text {rd }}$ ed.). Maidenhead: Open University Press McGraw Hill Education.

Lave, J., \& Wenger, E. (1991). Situated learning:Legitimate peripheral participation. New York: Cambridge University Press.

Lessow-Hurley, J. (2013). The foundations of dual language instruction ( $6^{\text {th }}$ ed.). Boston: Pearson.

Leu, D. J., Kinzer, C. K., Coiro, J. L., \& Cammack, D. W. (2004). Toward a theory of new literacies emerging from the Internet and other information and communication technologies. In R. R. Ruddell \& N. J. Unrauh (Eds.), Theoretical models and $\quad$ processes of reading ( $5^{\text {th }}$ ed., pps. 1570-1613). Newark, DE: International Reading Association.

Leu, D. J., Mallette, M. H., Karchmer, R., \& Kara-Soteriou, J. (2005). Contextualizing the new literacies of information and communication technologies in theory, research, and practice. In R. A. Karchmer, M. H. Mallette, J. Kara-Soteriou, \& D. J. Leu (Eds.), Innovative approaches to literacy education: Using the Internet to support new literacies (pp. 1-10). Newark, DE: International Reading Association.

Lewis, C., Enciso, P., \& Moje, E.B. (2007). Introduction: Reframing sociocultural research on literacy. In C. Lewis, P. Enciso, \& E.B. Moje (Eds.), Reframing sociocultural research on literacy: Identity, agency, and power (pp.1-14). New York, NY: Routledge.

Luke, A. (2004). On the material consequences of literacy. Language and Education, 18(4), 331-335.

Martin, A. (2006). Literacies for the digital age. In M. A \& M. D (Eds.), Digital Literacies for Learning (pp. 3-25). London: Facet.

McDermott, R., \& Varenne, H. (1995). Culture "as" disability. Anthropology in Education Quarterly, 26(3), $324-348$.

Moje, E.B., \& Luke, A. (2009). Literacy and identity: Examining the metaphors in history and contemporary research. Reading Research Quarterly, 44(4), 415-437.

Motha, S. \& Lin, A. (2014). "Non-coercive rearrangements": Theorizing Desire in TESOL. TESOL Quarterly, 48(2), 331-359.

National Council of Teachers of English. (2008). The NCTE definition of 21st century literacies. Retrieved from http://www.ncte.org/positions/statements/21stcentdefinition

New London Group. (1996). A pedagogy of multiliteracies: Designing social futures. Harvard Educational Review, 66(1), 60-92.

Norton Pierce, B. (1995). Social identity, investment, and language learning. TESOL Quarterly, 29(1), 9-31.

Norton, B. (1997). Language, identity, and the ownership of English. TESOL Quarterly, 31(3), 409-429.

Norton, B. (2000). Investment, acculturation, and language loss. In I. S. McKay \& S. L. C. Wong (Eds.), English language learners in the United States: A resource for teachers (pp. 443-461). New York: Cambridge University Press.

Norton, B. \& Pavlenko, A. (2004). Addressing gender in the ESL/EFL classroom. TESOL Quarterly, 38(3), $504-514$.

Norton, B., \& Toohey, K. (2011). Identity, language learning, and social change. Language Teaching, 44(04), 412-446. doi: $10.1017 / \mathrm{s} 0261444811000309$

Norton, B., \& Williams, C. J. (2012). Digital identities, student investments, and eGranary as a placed resource. Language and Education, 26(4), 315-329.

Ohler, J. (2009). New-media literacies. Education Digest, 75(3), 31-36.

Pavlenko, A. (2001). Bilingualism, gender, and ideology. International Journal of Bilingualism, 5(2), 117-151.

Seidlhofer, B. (2005). English as a lingua franca. ELT Journal, 59(4), 339-341. doi:10.1093/elt/ccio64

Shelby-Caffey, C. V., Caffey, R. A., Caffey, C. A., \& Caffey, K. A. (2014). The promise of remix: An open message to educators. Voices from the Middle, 21(4), 47-53. 
Siegal, M. S. (1994). Looking east: Learning Japanese as a second language in Japan and the interaction of race, gender and social context. Unpublished doctoral dissertation. University of California, Berkeley: California, USA.

Taffe, S. W., \& Bauer, L. B. (2013). Digital literacy. In B. M. Taylor, \& N. K. Duke (Eds.), Handbook of effective literacy instruction: Research-based practice K-8 (pp. 162-188). New York: The Guilford Press.

Tysseling, L. A. (2015). New literacies. In D. G. Litt, S. D. Martin, \& N. A. Place (Eds.), Literacy teacher education: Principles and effective practices (pp. 169-199). New York: The Guilford Press.

Warschauer, M. (2010). Digital literacy studies: progress and prospects. In M. Baynham \& M. Prinsloo (Eds.), The future of literacy studies (pp. 123-140). Houndmills, Basingstoke, UK:Palgrave Macmillan.

Weedon, C. (1987). Feminist Practice and Post-structuralist Theory. Oxford: Basil Blackwell.

Wenger, E. (1998). Communities of practice: Learning, meaning, and identity. New York: Cambridge University Press. Wortham, S. (2004). From good student to outcast: The emergence of a classroom identity. Ethos, 32(2), 164-187.

Zuengler, J. (1989). Identity and IL [interlanguage] development and use. Applied Linguistics, 10(1), 80-96. 